\title{
Performance of Community Services in Universitas Negeri Surabaya
}

\author{
Lutfi Saksono ${ }^{1, *}$ Rojil Nugroho Bayu Aji² Muamar Zainul Arif ${ }^{3}$
}

\author{
${ }^{1}$ German Department, Universitas Negeri Surabaya Surabaya, Indonesia \\ ${ }^{2}$ History Department Universitas Negeri Surabaya Surabaya, Indonesia \\ ${ }^{3}$ Mechanical Engineering Department, Universitas Negeri Surabaya Surabaya, Indonesia \\ ${ }^{*}$ Corresponding author. Email: llutfisaksono@unesa.ac.id
}

\begin{abstract}
Community service is a concrete manifestation of the application of science, so the result will not only empower the community and strengthenthe nation's competitiveness but will further build and strengthen education and research. Community service can be applied and implemented in various spaces and communities. As a university in Indonesia, theUniversitas Negeri Surabaya must also carry out community service which is managed by the Institute forResearch and Community Service (LPPM). So far, community service has been implemented in various places in Indonesia and has an impact on the community. Therefore, these activities must be improvedboth in quantity and quality. Unesa's community services must be carried out in a planned, consistent, andsustainable manner, to produce a good outcome and leadto the commercialization of innovations that can generate revenue for Unesa. To find out the efforts of Unesa to achieve the goal of community service, we can measure through performance measurement. Performance measurement is an attempt to determine the level of success of an organization. Performance measurement aims to assess the current position of the organization and also to help managers create and implement better strategies. The performance of community service at Universitas Negeri Surabayawhich was funded by the government through the Directorate of research and community service in thelast five years (2016-2020) was not very good. Therefore, serious efforts are needed to increase the number of community service proposals funded by the government. On the other hand, community service funds through Unesa funds continue to increase.
\end{abstract}

Keywords: community service, performance, performance measurement

\section{INTRODUCTION}

Universities play an important role in social movements and the application of science [1]. The application of knowledge in society by universities in Indonesia cannot be separated from the threefold missions of higher education, namely education, research, and community service. Community Service is inseparable from education and research. It is a concrete manifestation of the application of science, so the result will not only empower and empower the community and strengthen the nation's competitiveness but will further build and strengthen education and research. It can be applied and implemented in various spaces and communities.

In the 2020 edition of the research and community service handbook published by the Directorate of Research and Community Service, Deputy for Research and DevelopmentStrengthening, Ministry of Research and Technology/ National Research and Innovation Agency, it is explained that the objectives of community service in higher educationare: (1) carry out community service following the Regulation of the Minister of
Education and Culture No. 3 of 2020 concerning National Higher Education Standards;

(2) develop a model of community empowerment; (3) increase the capacity of community service; (4) provide solutions based on academic studies of the needs, challenges, or problems faced by the community, either directly or indirectly; (5) carry out activities capable of empowering people at all levels, economically, politically, socially and culturally; and (6) transfer technology, science, and art to the community for the development of human dignity with gender equity and social inclusion as well asthe preservation of natural resources [2].

Based on the Regulation of the Minister of Education and Culture No. 3 of 2020 concerning National Higher Education Standards, there are 8 national standards for community service, namely standard results, standards, content, process standards, assessment standards, implementing standards, facilities, and infrastructure standards, management standards, and funding and financing standards. The standard of community service results is a minimum criterion that results from community service in applying, practicing, and civilizing 
science and technology to advance public welfare and educate the nation's life. The standard of content for community service is a minimum criterion regarding the depth and breadth of community service material that refers to the standard of community service results. The standard of the community service process is the minimum criteria for community service activities which consist of planning, implementing, and reporting activities. The standard of community service assessment is the minimum criteria for assessing the processand results of community service. The standard of implementing community service is a minimum criterion forthe ability of the implementer to carry out community service. The standard of community service facilities and infrastructure is a minimum criterion of the facilities and

The infrastructure is needed to support the community service process. Community service management standards are the minimum criteria for planning, implementing, controlling, monitoring, and evaluating, as well as reporting community service activities carried out by research and community service institutions. Standards for funding and financing community service, are the minimum criteria for sourcesand mechanisms for funding and financing community service through internal university funds, government funding, collaboration with other institutions, both at home and abroad, or funds from the community.

As a university in Indonesia, Universitas Negeri Surabaya must also carry out community service which is managed bythe Institute for Research and Community Service (LPPM). So far, community service in Unesa has been implementedin various places in Indonesia and has had an impact on the community. Therefore, these activities must be improved both in quantity and quality. Community service at Unesa must be carried out in a planned, consistent, and sustainable manner, to produce good outcomes for Unesa and lead to the commercialization of innovations that can generate revenue for Unesa.

The Institute for Research and Community Service (LPPM) Unesa which coordinates the community service is in charge of planning, coordinating, and evaluating community serviceactivities, whether sourced from ministry funds, Unesa funds, other agencies, or self-funding community serviceteams. A large number of sources of funds makes communityservice activities very attractive to lecturers. However, do community service activities at Unesa support Unesa's visionand mission and bring benefits to the campus and the community? This question needs to be answered if there is acomplete picture of community service activities carried out over the last five years. In addition, to support the reputation of universities in the future, the right development strategy isneeded.

Find out the efforts made by Unesa to achieve the goal of community service, it can be measured through performancemeasurement. Performance measurement is an attempt to determine the level of success of an organization. Performance measurement aims to assess the current positionof the organization and also to help managers create and implement better strategies [3].

\section{THEORIES}

Styles Every organization has goals to be achieved. Efforts to achieve goals and success in achieving organizational goals within a certain period are called performance [4]. According to Lebas [5]. performance is future-oriented, designed to reflect the peculiarities of each organization, and is based on a causal model linking various components and products. Performance can be positive and negative and is related to the results achieved in the past.

The performance of an organization is a portrait of all the resources owned by the organization, both physical such as humans and non-physical such as regulations, information, and policies. The concept of performance organization also illustrates that every public organization provides services to the community and performance can be measured using existing performance indicators to see whether the organization has done a good job and also to determine whether the goals that have been set have been achieved or not [6].

To find out the good and bad performance of an organization, it is necessary to measure the organization. Performance measurement is an attempt to measure and compare the results of activities or goals that have been achieved according to the initial planning and to compare the results and previous plans. It is not only the final target that needs to be measured and become a measure of the company's performance but also related to the competencies and processes that have been implemented. Performance measurement is very useful for organizations because it can be used as a measure of success in a certain period and can also be used as an evaluation and input for improvement or improvement of organizational performance and strategic planning in the future [7]-[10]. The use of performance measurement information will provide positive changes in organizational culture, systems, and processes, help set agreed with performance goals, allocate and prioritize resources, inform managers to confirm or change current policies or directions. to achieve those goals, and share performance results in pursuit of goals has been discussed in [11].

Organizational performance measurement can include inputs, processes, outputs, results, benefits, and impacts. Input is everything that is needed for the implementation of the activities carried out to produce output has been reported in [6]. The process is a measure of activity including the steps specified in carrying out 
the activity. Output is the achievement of tangible or intangible activities. Results are general descriptions of the actual or expected results of goods or services produced by an organization. Benefits are something related to the ultimate goal of carrying out activities. The impact is the influence of both positive and negative.

\section{METHOD}

Performance measurement can be done by comparing the realization with the target presented through the calculation of achievements. To calculate achievement, the following formulas (1) and (2) are generally used:

a. If the greater the realization indicates the better performance or the smaller the realization indicates the worse performance, the formula is used:

achievement $=\frac{\text { realization }}{\text { Target }} \times 100 \%$

b. If the greater the realization indicates the worse performance or the smaller the realization indicates the better performance, the formula is used:

$$
\text { achievement }=\frac{(2 \times \text { Target }) \text {-realization }}{\text { Target }} \times 100 \%
$$

\section{RESULTS AND DISCUSSION}

To improve community empowerment in both the economic and non-economic sectors, the government through the directorate of research and community service provides competitive grants in the field of community service to universities every year. To participate in the competitivegrant, community service implementers from each university must submit a proposal and follow the selection process. There are several types of grants offered by the government, including community service grants, Technology Dissemination Program grants to the community (PDTM), and Application of Appropriate Technology to the Community (PPTTG).

Table 1. Community Services funded by DRPM

\begin{tabular}{|c|c|c|c|c|c|c|c|c|c|c|}
\hline \multirow[t]{3}{*}{ year } & \multicolumn{10}{|c|}{ Community services funded by DRPM } \\
\hline & \multicolumn{3}{|c|}{ Abdimas } & \multicolumn{3}{|c|}{$\begin{array}{c}\text { PDT } \\
\text { M }\end{array}$} & \multicolumn{3}{|c|}{$\begin{array}{c}\text { PPT } \\
\text { TG }\end{array}$} & \multirow[t]{2}{*}{ NFP* } \\
\hline & $\begin{array}{l}S \\
*\end{array}$ & $\mathrm{~T}^{*}$ & $\mathrm{~F}^{*}$ & $\mathrm{~S}^{*}$ & $\mathrm{~T}^{*}$ & $\mathrm{~F}^{*}$ & $\mathrm{~S}^{*}$ & $T^{*}$ & $\mathrm{~F}^{*}$ & \\
\hline 2016 & 123 & 25 & 52 & - & - & - & - & - & - & 52 \\
\hline 2017 & 105 & 25 & 29 & - & - & - & - & - & - & 29 \\
\hline 2018 & 92 & 25 & 22 & 15 & 2 & 3 & - & - & - & 25 \\
\hline 2019 & 98 & 25 & 28 & 20 & 2 & 2 & $\begin{array}{l}2 \\
2\end{array}$ & 1 & 2 & 32 \\
\hline 2020 & 60 & 25 & 9 & 22 & 2 & - & $\begin{array}{l}1 \\
2\end{array}$ & 1 & 1 & 10 \\
\hline
\end{tabular}

$\mathrm{s}=$ submitted, $\mathrm{T}=$ target, $\mathrm{F}=$ Funded, $\mathrm{NFP}=$ Number of funded proposals
The table 1 shows that there are 3 types of community service grants that UNESA lecturers have participated in thelast 5 years. Based on the table, 2016 was the year the most proposals were collected, and also the proposals were funded. The Unesa Research and Community Service Institute (LPPM) has set a target of 25 proposals funded from the 123 proposals submitted. In reality, 52 proposals were received and funded or $42 \%$ of the proposals. This means that it exceeds the set target or around 208\%. In 2017there were 105 proposals submitted to grants but only 29 proposals or about $28 \%$ were funded. This means that there are still around $116 \%$ of the target set and a decrease of about $44 \%$ compared to 2017. In 2018 the proposals enteredin the competition grants amounted to 92 abdimas granttitles and 15 PDTM proposal titles, while only 22 abdimas grant titles and 3 PDTM proposals were received. PDTM proposals or about $23 \%$ of the proposals entered into the competition. This means that in 2018 the achievement of the abdimas grant was only $88 \%$ of the target set and the achievement of the PDTM was $150 \%$ of the target set. In 2019 there was an increase in funded proposals compared to 2018 , which was around $1.68 \%$ or 28 abdimas grant proposals or the achievement was $112 \%$ of the set target. Meanwhile, the PDTM grant decreased compared to 2018 but met the targets set and there was an increase in PPTTG grants. In 2020 there were only 60 abdimas grant proposals from Unesa participating in the competition and only 9 proposals were funded or the achievement was only $36 \%$ of the target set. Meanwhile, none of the 22 PDTM proposals was funded. In addition, there is only 1 PPTG proposal that is funded from the 12 proposed proposals. This means thatin 2020 there will only be 10 proposals from Unesa funded by the DRPM.

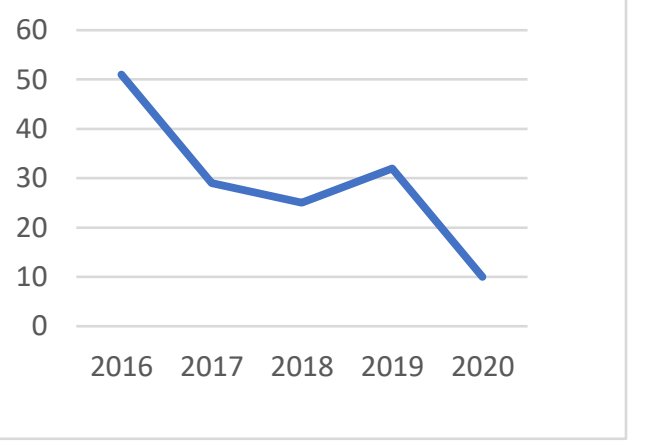

Figure. 1 number of community service proposals funded by DRPM

The graph above shows a significant decline in proposals funded by DRPM in the last five years. This shows that the performance of community service at the State University of Surabaya in competitive grants at the national level is not good. 
Several factors cause the number of proposals funded to below. First, the level of competition is getting tougher, because many universities are submitting proposals. Second, the funds disbursed by the DRPM decreased. Third, the interest of Unesa lecturers to take part in the competitive offer is low. These factors must be addressed by Unesa to compete at the national level.

In addition to funds from the DRPM, the implementation of community service is also funded by Unesa. Funding from Unesa is divided into 2, namely funding managed by the faculty and funding managed by LPPM Unesa. The following is data on community service activities whose funding is managed by the faculty.

Table 2. Community services funded by faculties

\begin{tabular}{|c|r|r|r|r|r|r|r|r|r|}
\hline Year & \multicolumn{1}{|c|}{ FBS } & FIP & FIO & FISH & FT & \multicolumn{1}{|c|}{ FMI } & FEB & Pasca & \\
\hline 2016 & 45 & 40 & 11 & 27 & 37 & 39 & 18 & 14 & 231 \\
\hline 2017 & 37 & 42 & 11 & 27 & 46 & 43 & 20 & 18 & 244 \\
\hline 2018 & 40 & 42 & 19 & 28 & 46 & 41 & 20 & 27 & 263 \\
\hline 2019 & 42 & 42 & 20 & 24 & 48 & 41 & 22 & 27 & 266 \\
\hline 2020 & 36 & 35 & 21 & 23 & 58 & 34 & 30 & 48 & 285 \\
\hline Total & 200 & 201 & 82 & 129 & 235 & 198 & 110 & 134 & 1289 \\
\hline
\end{tabular}

Based on table 2, the number of community services funded by the faculty continues to increase from year to year. In 2016 the number of community services was 231 and increased to 244 titles in 2017. Meanwhile, in 2018 there was an increase in the number of titles to 263 proposals. An increase also occurred in 2019. There were 266 community service titles or an increase of $1.1 \%$. In 2020 there were 285 titles or an increase of $7.1 \%$.

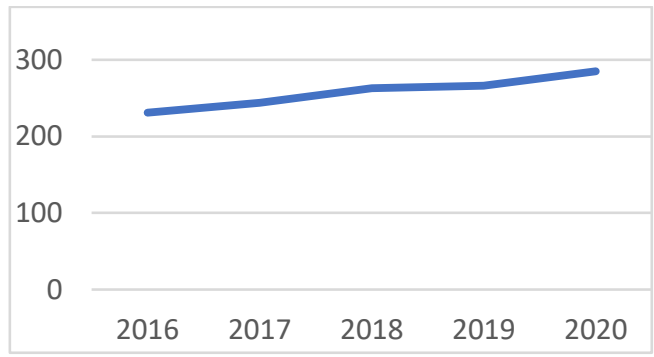

Figure 2 number of proposals for community service funded by the faculty

In 2020, community service funding for faculty and postgraduate policy schemes has increased compared to previous years. Indeed, several faculties reduce the number of community services such as FBS, FIP, FISH, and FMIPA. But the overall number has increased.

Meanwhile, since 2018 there have been 14 proposals for community service whose funding is managed by LPPM. In 2019 it increased to 33 funded community service proposals. In 2020 there was an increase in the number of community service funded through LPPM. The increase was $63 \%$ or there were 89 proposals funded. This increase occurred because community service was focused on handling Covid-19. The following is a graph of the number of community services funded.

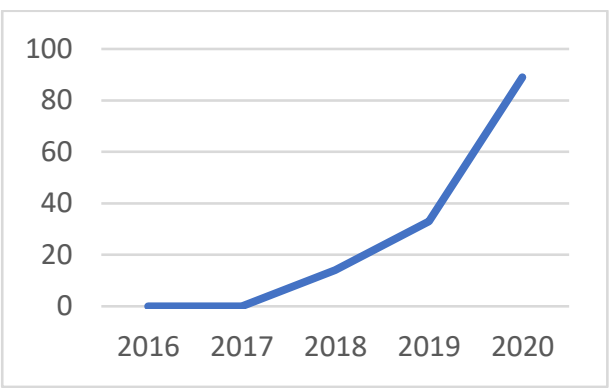

Figure 3 number of community service proposals funded by LPPM

Community services funded by faculties and LPPM will be very helpful in assessing the clustering of higher education institutions in the field of community service. In 2019 Unesa's community service cluster was in the superior cluster. This is inseparable from the number of community services funded by faculty and LPPM or university.

\section{CONCLUSION}

The performance of community service in Universitas Negeri Surabaya which was funded by the government through the Directorate of research and community service in the last five years (2016-2020) wasvery bad. Therefore, we need serious efforts to increase the number of community service proposals funded by the government. On the other hand, community services funded by faculties, LPPM, or university tend to increase.

\section{REFERENCES}

[1] G Nuangchalerm, Prasart and Chansirisira, Pacharawit, Community Service and University Roles: An Action Research Based on the Philosophy of Sufficiency Economy (May 5, 2012). US-China Education Review. 4: 453459, 2012, Available at SSRN: https://ssrn.com/abstract $=2437281$

[2] Direktorat Riset dan Pengabdian Masyarakat. Panduan Penelitian Dan Pengabdian Kepada Masyarakat Edisi XIII Tahun 2020. 2020

[3] Cristian-Ionuţ Ivanov and Silvia Avasilcăi. Performance Measurement Models: An Analysis for Measuring Innovation Processes Performance Procedia - Social and Behavioral Sciences 124 ( 2014 ) $397-404$.

[4] Aditama, Pria Bintang \& Nina Widowati. 2017. Analisis Kinerja Organisasi Pada Kantor Kecamatan Blora. Journal of Public Policy And Management Review. Vol. 6 (2). Pp 283-295. 
[5] Elena-Iuliana, Ion and Maria, Criveanu. 2016. Organizational Performance - A Concept That Self-Seeks to Find Itself. Annals of the „Constantin Brâncuşi”, University of Târgu Jiu, Economy Series, Issue 4/2016. Pp. 179-183.

[6] Silitonga, P. Eddy Sanusi and Widodo, Djoko Setyo. 2017. Organizational Performance Analysis: Organizational Commitment, Competence and Organizational Culture (Study on Bekasi City Government). International Journal of Recent Scientific Research, Vol. 8 (4) pp. 16732-16740

[7] Sulisworo, Dwi. 2009. Pengukuran Kinerja. Jogjakarta: Universitas Ahmad Dahlan

[8] Handayani, Bestari Dwi. 2011. Pengukuran Kinerja Organisasi Dengan Pendekatan Balanced Scorecard Pada Rsud Kabupaten Kebumen. Jurnal Dinamika Manajemen. Vol. 2, No. 1, 2011, pp: 78-91

[9] Antari, Ni Wayan Yoshi \& I Putu Sudana. 2016. Strategi dan Pengukuran Kinerja Badan Rumah Sakit Umum Tabanan dengan Pendekatan Balanced Scorecard. Jurnal Akuntansi Universitas Udayana Vol.15.3. pp. 22402268.

[10] Suryani, Ni Kadek \& John E.H.J. FoEh. 2018. Kinerja Organisasi. Sleman: Penerbit Deepublish

[11] Amaratunga, Dilanthi et al. 2001. Process improvement throughperformance measurement: the balanced scorecard methodology. WorkStudy Journal. Volume 50. (5). pp. 179-188 